〔822]

\title{
残留性有機塩素化合物による人体及び \\ 食品の污染とブリの污染指標としての役割

\author{
Organochlorine Residues in Human Tissues and Some Foodstuffs, \\ and the Role of Yellowtails as an Index of the Residues
}

千葉大学医学部環境疫学研究施設農村医学研究部

高 宮 恒 治

Koji Takamiya

Department of Rural Health, Institute of Environmental Health,
School of Medicine, Chiba University, Chiba

The general population and the environment are still polluted with residual organochlorine compounds such as DDT, PCB etc., whose production and use were prohibited in Japan in more than 10 years ago.

At first, 13 species of human autopsy tissues and blood of rural residents were investigated for residues of organochlorine insecticide $(\mathrm{OCI})$ and indications of their transfer from maternal blood to umbilical cord blood at delivery. Some species of marine fishes, fatty foods, chickens and eggs were surveyed for their OCI content.

Based on the data of these surveys, wild and cultured yellowtails were selected as indices of a variety of marine fishes. The characteristics of these yellowtails were examined, and their levels of OCI and PCB were investigated during a period from 1979-83. The conclusions are presented as follows:

1) It is suggested that the organochlorine levels of both types of yellowtail have increased approximately in proportion to the increase of lipid content followed by growth. Besides the difference of the young and mature fishes with respect to the qualities of DDT and PCB residues indicates that their metabolic functions are enhanced by their growth.

2) The wild yellowtails caught in the Nagasaki area in 1981 showed high amounts of DDT and high ratios of technical DDT per total DDT. These facts and the GLC patterns of PCBs in these yellowtails indicate a high level of DDT content in the Japan Current.

3) DDT contents of both wild and cultured yellowtails decreased qualitatively in 1983 as compared with two years before. These facts and the fluctuations observed in total DDT are considered to be a sign of the decline of the yellowtail.

4) It is concluded from the standpoint of ecology that the DDT content on lipid basis in the general population is concentrated as compared with that in marine fishes.

5) PCBs GLC pattern of the cultured yellowtail was obviously different from that of the wild type in 1980, and thereafter their patterns have come to be similar. The levels of PCB content were the same and didn't change distinctly from 1980 to ' 83 in either type.

Key words : Organochlorine residues, Index, Yellowtail monitoring, General population, Biologic concentration

残留性有機塩素化合物, 指標, ブリ監視, 一般住民, 生物濃縮 


\section{緒}

$$
\text { 言 }
$$

$\mathrm{DDT}$ ・BHCによって代表される有機塩素系殺虫肪（以 下 OCI と記す)や PCB 等の有機塩素化合物は, 強い生体 残留性と生物濃縮性を有するために，いったん環境に放 出されたものが，食物連鎖系などによる循環を経て一般 住民にとりこまれ，その体内殊に，母乳が污染されてい ることが明らかになり, 我が国では1972年をもって製造 と使用が，行政的にほほ全面的に禁止された。しかしな がら，我が国一般住民における OCI の残留レベルは，そ の後低下しているとはいえ, 殊に DDT の場合は, 極めて 緩慢に推移している( ${ }^{123)}$ 。その理由としては, DDT・BHC は熱帯地域の発展途上国で, 主にマラリヤを予防するた めの対策上, 依然として使用されるとの長期的予測 4 (5) が あることと, これらの農薬が, 共産圏の中国・ソ連等6,7) では，いまだに使用されている可能性があるためである。 田辺ら ${ }^{8)}$ による我が国をとりまく環境 (大気と表層海水) の調査によれば, 北西太平洋の中緯度地域では, DDT 及 び BHCによる污染レベルが高い8)。そのほか Meadows ら ${ }^{9}$ によれば DDT の場合, 地球的規模でその使用量が 減少しても, 海洋の魚類の残留值は, 更に長期に渡って 增加すると予測されるという。

これらの化合物による環境污染と生態系の破壊につい ては，レーチェル・カーソンによる著述 SILENT SPRING $^{10)}$ により強く警告された。しかしながら，それ を実証する有害影響については，従来一般住民に対する よりも，生態系すなわち環境に生息する種々の生物への 作用が報告されていて，DDT では野鳥のカルシュウム

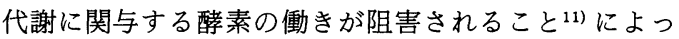
てふ化率が低下し，ある種の野鳥が絶滅に追いこまれた ことなどが知られている。そのほか BHCでは, 我が国 に扔ける水田の昆虫相への有害作用 ${ }^{12)}$ が報告されてい る。これらの化合物が，常時人体に残留することによっ てじゃつ起される有害作用については, 明らかではない $か^{13)}$, De Vlieger ら ${ }^{14)} は$, DDT・dieldrin の中枢神経系 への残留は，血液を上回ると報告している。そのほか, 近年これらの化合物が, 一般住民の発癌に補助的に関与 している可能性が強(15) とされ, 新たに注目されるに至 つている。従って, 我が国一般住民の残留レベルについ ては，予防医学的観点から監視を継続する必要があると 考えられる。

DDT 等残留性の OCI による一般住民の体内污染につ いては，これまで国内のみならず，国際的16,17) に広く調 查研究がなされ, 報告されている。著者は, 病理解剖症
例を対象に選び，各種の臟器組織について残留分析を実 施し, 次に OCI の妊婦から胎児への移行の実態を知るた めに, 出産時の母体血とさい帯血及び胎盤を調査したほ か, 農村住民から血液の供与をえて, 同様の調查を行い 若干の知見を得た。

次いで, 我が国一般住民の OCI の主要な污染源とされ る海洋性魚類 ${ }^{18)}$ を中心に, その残留レベルが比較的高い 可能性のある若干の脂肪性食品と鷄肉・鷄卵をとり上げ, OCI の蓄積の実態を調査した。

更に，海洋性魚類の中で，ブリは污染レベルが高いほ か, 天然のブリは本邦近海を南北に移動しながら回遊す る大型魚であることから，本邦近海に生息する魚類の污 染指標として適しているものと考えられる。そこで天然 ブリを指標として取り上げ，ほかにその養殖魚を対照と して, DDT・dieldrin・PCB による污染の推移を，隔年 ごとに経時調査した。

\section{調 査 方 法}

\section{1. 試料の入手}

人体の藏器組織は, 病理解剖時に症例ごとに, 5 種類 の組織を分与された。入手時期は，1974年 2 月から 6 月 までである。農村住民(17名，千葉県四街道市鹿放地区) の血液は，'75年 4 月 9 日に朝食をぬき空腹時に採取し た。胎盤，母体血及びさい帯血は，75年 3 月から 5 月ま でに, 千葉市W産婦人科医院にて, 産婦の出産時に提供 された。

食品については，マーガリンとバターは， 5 社の製品 各 1 試料を調査した。会社名はマーガリンでは, 日本生 活協同組合連合会，雪印乳業，味の素，日本リーバ・イ ンダストリーズ，明治乳業，同じくバターでは，雪印乳 業, 明治乳業 (帯広及び稚内工場), 森永乳業, 北海道農 協乳業であった。マーガリン, バター, 豚脂, 魚類 (ア ジ，マグロ，ブリ）は，主として千葉市の商店より, '77 年10月から翌 78 年 3 月の間に入手した。

ブリの幼魚と成魚を比較した試料は，いずれも 5 尾で, 体重の平均值は，天然ブリでは $0.71 \mathrm{~kg}$ (幼魚）と $9.7 \mathrm{~kg}$ (成魚)又養殖産では, 幼魚が $1.0 \mathrm{~kg}$ で成魚では不明であ った。これらのブリと鵴肉・鶏卵の入手時期は，78年12 月から翌 79 年 3 月の間である。入手先は, 養殖の幼魚 は，千葉県富浦町魚協でその他のブリは，千葉市及び千 葉県大網白里町の販売店より, 鵴肉・鵴卵は, 千葉市の 商店及び四街道市の養䳕農家である。

次に, DDT・dieldrin の経年的推移を調查したブリ は，'79年 2 月〜 3 月と ' 81 年及び' 83 年の同時期に，同様 
にPCB については, '80年 1 月〜 3 月及び ' 82 年, '83年の 同時期に入手した。体重の平均値は, 天然ブリでは, '81 年の $6.7 \mathrm{~kg}$ が最小, 83 年の $10.4 \mathrm{~kg}$ が最大であったが, 養殖産では, 平均值の幅が $4.3 \sim 4.6 \mathrm{~kg}$ と小さく大きさ がほほ均一であった。試料数は, 天然産, 養殖産のいず れも 5 尾（'82年の天然産のみ 4 尾）であった。 なお，検体の採取量は，魚肉・旌肉・鵴卵の場合 $10 \mathrm{~g}$, その他では約 $1 \mathrm{~g}$ とした。又，マグロ以外の魚類の検査 部位は, 近頭部の可食肉とした。

2 . 検查方法

2.1 脂質の抽出法と OCI のクリーンアップ

人体臓器の脂質抽出法については, Chart 1 に示す操 作により，エタノールで均一化し，n一キキンによる加 温抽出を繰り返した後に，各抽出液を合わせ，溶媒を留 去して得た。クリーンアップについては, '70年に設定さ れた母乳中の $\beta$-BHC を中心とする残留有機塩素郕の 実態調査法 ${ }^{199}$ に準じた。
胎盤では, Chart 1 に従って脂質を抽出し, その後の操 作は，おおむね前述の方法によった。しかし，脂質の含 有量が少ないため, カラムクロマトグラフィーでは，内 径 $10 \mathrm{~mm}$ 長さ約 $30 \mathrm{~cm}$ のクロマト管に, フロリジルを 5 $\mathrm{g}$ 充てんし, 試料は, $15 \%$ エーテル・ヘキサン $50 \mathrm{ml}$ で展 開した。

血液の場合も，同じく'70年に設定された方法 ${ }^{17}$ におお む称従った。

魚肉, 鷄肉の脂質抽出操作は, Chart 1 にならったが, エタノール分画の脂質は, 更に同量の蒸留水と $\mathrm{n}$-へキサ ンを加え， $\mathrm{n}$ ーキキンで抽出した。

鷄卵については, Pesticide Analytical Manual ${ }^{20)}$ を参 考にした。

なお, GCでは $2 \mathrm{~m}$ カラムを用い充てん剤の液層は，2 $\% \mathrm{QF}-1, \mathrm{DEGS}-\mathrm{H}_{3} \mathrm{PO}_{4}(2-0.5 \%), 2 \% \mathrm{OV}-17$ であ る。

$2.2 \mathrm{PCBs}$ の抽出・精製と測定

\section{Chart 1 Procedure of lipid extraction.}

Sample (less than $10 \mathrm{~g}$ )

Homogenize with EtOH $(30 \mathrm{~m} l)$

Centrifuge at 2,500 r.p.m. for $5 \mathrm{~min}$.
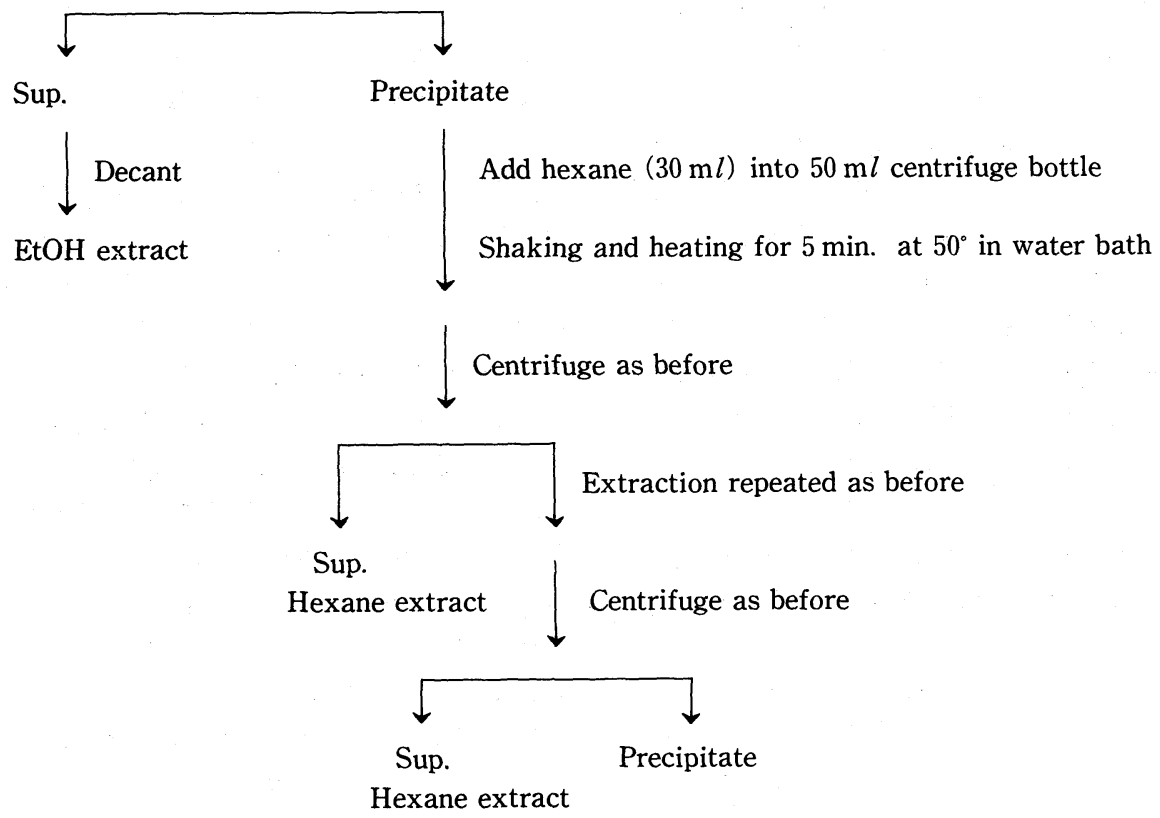
抽出・精製は, 脇本ら ${ }^{21)}$ の方法に準じた。GCによるピ ークパターンについては, OV-17, OV-1 カラム（2％, $2 \mathrm{~m}$ ）を用い，高松ら ${ }^{22)}$ の方法にならった。基準ピーク は, 全体のほほ中央にありその高さが, 基準値として適 当であるか検討して選んだ。

定量では, 能勢ら ${ }^{23)}$ の完全塩素化法を応用して開発し

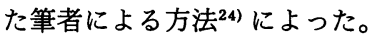

その原理は，次式によって表される。

a $\mu$ g (PCBs : KC-300, 400, 500, 600) $\rightarrow$

b $\mu \mathrm{g}$ (Decachlorobiphenyl)

$\mathrm{b} / \mathrm{a}=1.1$, 反応温度 : $64 \sim 67^{\circ}$

反応時間：45分

PCB 值は, 生成した Decachlorobiphenyl (DeCB) 值 から, 容易に求められる。DeCB の定量に用いたカラム( $1 \mathrm{~m})$ の液層は, $\mathrm{DEGS}-\mathrm{H}_{3} \mathrm{PO}_{4}(2-0.5 \%)$ 又は $1 \% \mathrm{OV}$ -1である。

\section{調 査 結 果}

1. OCI の人体内残留

$1.1 \mathrm{BHC} \cdot \mathrm{DDT} \cdot$ dieldrin の臓器組織濃度と分布
調查対象の性別・年龄構成は, 10 例中過半数の 8 例が 男性で, 半数に当たる 5 例が60歳代であった。検索した 試料は, 13種類の臟器組織由来の50検体であるが, 検体 数が少ないため, 対象の年齢, 職業, 疾病を考慮せずに 性別と臟器別に, 各塩素化合物の濃度レベルを求め, Table 1 に示した。分析した化合物は 3 種の BHC 異性 体と $\mathrm{pp}^{\prime}$-DDT・pp'-DDE 及び dieldrin である。いずれの 化合物も一様に腸間膜の濃度が最高, 脾蔵と肺臓のレベ ルが最低で, これらの化合物の脂質蓄積性が認められた。 体内藏器組織の濃度分布について，その傾向をより正 確に把握するために, 年齢の近似した60歳代男性の 3 症 例について, 4 種の臟器 (腸間膜, 副腎, 箤丸, 肝臓) の蓄積レベルをみると, $\beta$ - $\mathrm{BHC}$ と $\mathrm{pp}^{\prime} \cdot \mathrm{DDE}$ が同程度で dieldrinがこれより低い傾向にあった。各化合物の蓄積 性についても, これらの肝臟の濃度を基準にした各臟器 の濃度比から，蓄積レベルと同様の傾向がみられた。

\section{2 農村住民の血液に残留する $\mathrm{OCI}$}

対象は，男性17名でその年齢構成は，50歳代が 1 名の ほかは,すべて40歳代であった。

残留値は, $\beta$-BHC と $\mathrm{pp}^{\prime} \cdot \mathrm{DDE}$ の平均值が近似してい

Table 1 OCI average contents in 13 species of human tissues.

\begin{tabular}{|c|c|c|c|c|c|c|c|c|}
\hline Tissue & Sex & $\mathrm{N}$ & $\alpha-\mathrm{BHC}$ & $\beta$-BHC & $\gamma-\mathrm{BHC}$ & $\mathrm{pp}^{\prime}-\mathrm{DDE}$ & $\mathrm{pp}^{\prime}-\mathrm{DDT}$ & Dieldrin \\
\hline \multirow[t]{2}{*}{ Mesentery } & M & 7 & 0.005 & $1.2 \pm 0.75$ & $0.014 \pm 0.012$ & $1.1 \pm 0.79$ & 0.29 & $0.13 \pm 0.12$ \\
\hline & $\mathrm{F}$ & 1 & 0.033 & 0.40 & 0.033 & 0.57 & 0.13 & 0.058 \\
\hline \multirow[t]{2}{*}{ Adrenal } & M & 5 & 0.004 & $0.74 \pm 0.61$ & $0.010 \pm 0.013$ & $0.66 \pm 0.60$ & 0.11 & $0.080 \pm 0.093$ \\
\hline & $\mathrm{F}$ & 1 & 0.002 & 0.32 & 0.005 & 0.73 & $0.05>$ & 0.024 \\
\hline \multirow[t]{2}{*}{ Spleen } & M & 4 & $0.001>$ & 0.017 & $0.001>$ & 0.024 & $0.05>$ & 0.002 \\
\hline & $\mathrm{F}$ & 1 & $0.001>$ & 0.008 & $0.001>$ & 0.005 & $0.05>$ & $0.001>$ \\
\hline \multirow[t]{2}{*}{ Pancreas } & M & 3 & 0.001 & 0.22 & 0.002 & 0.25 & 0.06 & 0.017 \\
\hline & $\mathrm{F}$ & 1 & 0.005 & 0.078 & 0.008 & 0.093 & $0.05>$ & 0.013 \\
\hline \multirow{2}{*}{$\begin{array}{l}\text { Reproductive } \\
\text { organ }\end{array}$} & Testis & 6 & $0.001>$ & $0.035 \pm 0.026$ & 0.002 & $0.083 \pm 0.09$ & $0.05>$ & $0.005 \pm 0.003$ \\
\hline & Ovary & 1 & 0.006 & 0.021 & 0.002 & 0.062 & $0.10>$ & 0.004 \\
\hline \multirow[t]{2}{*}{ Liver } & M & 6 & 0.001 & $0.077 \pm 0.014$ & 0.001 & $0.065 \pm 0.025$ & $0.005>$ & $0.019 \pm 0.014$ \\
\hline & $\mathrm{F}$ & 2 & 0.003 & 0.25 & 0.004 & 0.35 & 0.08 & 0.024 \\
\hline \multirow[t]{2}{*}{ Kidney } & M & 3 & 0.002 & 0.11 & 0.002 & 0.075 & 0.03 & 0.019 \\
\hline & $\mathrm{F}$ & 2 & $0.001>$ & 0.020 & 0.001 & 0.059 & 0.02 & 0.003 \\
\hline Spinal cord & M & 2 & 0.002 & 0.50 & 0.006 & 0.56 & 0.18 & 0.060 \\
\hline Lung & M & 2 & $0.001>$ & 0.027 & 0.001 & 0.022 & $0.05>$ & 0.001 \\
\hline Subcutis & M & 1 & 0.002 & 1.4 & 0.008 & 0.52 & 0.19 & 0.088 \\
\hline Muscle & M & 1 & 0.002 & 0.068 & 0.001 & 0.023 & $0.05>$ & 0.007 \\
\hline Heart & $\mathrm{F}$ & 1 & 0.002 & 0.25 & 0.004 & 0.50 & 0.08 & 0.022 \\
\hline
\end{tabular}


Table 2 Residual levels of $\beta-B H C$ and $\mathbf{p p}^{\prime}-\mathrm{DDE}$ in human blood and placenta.

\begin{tabular}{lrcc}
\hline Specimen & $\mathrm{N}$ & $\begin{array}{c}\beta \text {-BHC } \\
\text { Mean } \pm \text { SD }\end{array}$ & $\begin{array}{c}\mathrm{pp}^{\prime}-\mathrm{DDE} \\
\text { Mean } \pm \mathrm{SD}\end{array}$ \\
\hline Umbilical cord blood & 10 & $1.9 \pm 1.1$ & $1.5 \pm 0.49$ \\
Maternal blood & 10 & $5.7 \pm 2.8$ & $5.5 \pm 2.0$ \\
Placenta & 9 & $6.8 \pm 2.8$ & $4.3 \pm 1.2$ \\
Blood of male rural resident & 17 & $4.6 \pm 3.7$ & $5.6 \pm 1.8$ \\
\hline
\end{tabular}

(ppb, whole basis)

るものの $\beta$ - $\mathrm{BHC}$ の標準偏差が $\mathrm{pp}^{\prime}-\mathrm{DDE} に$ 比べて大き く，個人差が顕著な傾向がみられた (Table 2)。又，両 化合物の残留値について，相互の関連は認められなかつ た $(\mathrm{r}=-0.015)$ 。

1.3 出産時の産婦血液・さい帯血・胎盤における OCI 残留值

対象の年齢構成は, 10名中 8 名が20歳代であった。分 析結果を Table 2 に要約して示した。 $\beta$-BHCと $\mathrm{pp}^{\prime}$ -
DDE がすべての検体に検出されたほか, dieldrin が母体 血と胎盤に検出されたが高々検出限界レベルであった。 母体血では， $\beta-\mathrm{BHC}$ と $\mathrm{pp}^{\prime}-\mathrm{DDE}$ の平均值が近似して いるが, 統計的には有意の相関性は認められなかった $(r=0.33)$ 。又, 胎盤やさい帯血でも母体血と同様に, 両 化合物の平均值が比較的近似していた。

3 種類の検体について, 両化合物の残留值を比較した 結果を Table 3 に示した。いずれの化合物でも，さい帯 血濃度は，一様に母体血のほほ30\%であったほか, さい 帯血と母体血の間に統計的に有意の相関性が認められた。

2 . 数種の食品に残留する $\mathrm{OCI}$

調査に供した食品とその OCI 残留値を Table 4 に示 した。分析した OCI は, BHCの 3 異性体, DDT とその 関連化合物, dieldrin 及びへプタクロールエポキシド $(H$. epoxide）である。

\section{1 魚類の OCI 残留值}

$\mathrm{pp}^{\prime}$-DDT のほかにその 3 種の関連化合物が検出され， そのいずれでも残留値は, ブリ>アジ>マグロの傾向が

Table 3 Relationship of $\beta$-BHC and $\mathrm{pp}^{\prime}$-DDE residues among placenta, umbilical cord and maternal blood.

\begin{tabular}{lrrrrr}
\hline \multicolumn{1}{c}{ Tissues } & \multicolumn{2}{c}{$\beta-\mathrm{BHC}$} & \multicolumn{2}{c}{$\mathrm{pp}^{\prime}-\mathrm{DDE}$} \\
& $\mathrm{N}$ & Ratio & $\begin{array}{c}\text { Correlation } \\
\text { coefficient }\end{array}$ & Ratio & $\begin{array}{c}\text { Correlation } \\
\text { coefficient }\end{array}$ \\
\hline Umibilical cord blood vs maternal blood & 10 & 0.33 & $+0.89^{* *}$ & 0.27 & $+0.72^{*}$ \\
Umibilical cord blood vs placenta & 9 & 0.27 & $+0.75^{*}$ & 0.34 & +0.65 \\
Maternal blood vs placenta & 9 & - & +0.59 & - & $+0.95^{* *}$ \\
\hline
\end{tabular}

$$
{ }^{*}: p<0.05,{ }^{* *}: p<0.01 \text {. }
$$

Table 4 OCI contents in several kinds of foodstuffs.

\begin{tabular}{|c|c|c|c|c|c|c|c|c|c|c|}
\hline \multirow{2}{*}{$\begin{array}{l}\text { Foodstuff } \\
\text { OCI }\end{array}$} & \multirow{2}{*}{ Tuna } & \multirow{2}{*}{$\begin{array}{c}\text { Jack } \\
\text { mackerel }\end{array}$} & \multirow{2}{*}{ Yellowtail } & \multicolumn{2}{|c|}{ Pork lipid } & \multirow{2}{*}{ Butter } & \multirow{2}{*}{ Margarine } & \multicolumn{2}{|c|}{ Egg } & \multirow{2}{*}{ Chicken** } \\
\hline & & & & (cooked) & (raw) & & & No. 1 & No. $2^{*}$ & \\
\hline$\alpha-\mathrm{BHC}$ & $\mathrm{ND} \sim 0.2$ & $0.4 \sim 2.8$ & $2.2 \sim 11.5$ & $\mathrm{ND} \sim 14$ & $3.7 \sim 8.7$ & $26 \sim 50$ & ND & $3.2 \sim 3.6$ & 0.25 & ND \\
\hline$\beta-\mathrm{BHC}$ & $\mathrm{ND} \sim 0.4$ & $\mathrm{ND} \sim 0.9$ & $\mathrm{ND} \sim 15$ & ND & ND & ND & ND & $7.4 \sim 8.8$ & 1.9 & ND \\
\hline$\gamma \cdot \mathrm{BHC}$ & $\mathrm{ND}$ & $\mathrm{ND} \sim 0.3$ & $\mathrm{ND} \sim 1.3$ & ND & ND & ND & $\mathrm{ND}$ & $1.7 \sim 2.0$ & ND & ND \\
\hline $\mathrm{pp}^{\prime}-\mathrm{DDT}$ & $\mathrm{ND} \sim 1.5$ & $3 \sim 26$ & $16 \sim 83$ & $\mathrm{ND} \sim 83$ & $13 \sim 88$ & ND & ND & $31 \sim 32$ & 3.0 & $\mathrm{ND} \sim 7.0$ \\
\hline $\mathrm{pp}^{\prime}-\mathrm{DDE}$ & $0.3 \sim 2.2$ & $1.8 \sim 9$ & $23 \sim 39$ & $30 \sim 34$ & $25 \sim 32$ & $16 \sim 20$ & ND & $15 \sim 17$ & 6.2 & $\mathrm{ND} \sim 13$ \\
\hline $\mathrm{op}^{\prime}$-DDT & - & $1 \sim 9$ & $6.2 \sim 18$ & ND & ND & ND & ND & ND & ND & ND \\
\hline $\mathrm{pp}^{\prime}-\mathrm{DDD}$ & - & $1 \sim 6$ & $13 \sim 20$ & ND & ND & ND & $\mathrm{ND}$ & ND & ND & ND \\
\hline Dieldrin & ND & $\mathrm{ND} \sim 0.9$ & $4 \sim 14$ & ND & $\mathrm{ND} \sim 5$ & ND & $\mathrm{ND}$ & $2.1 \sim 3.8$ & 1.2 & $\mathrm{ND} \sim 1.8$ \\
\hline H. epoxide & - & ND & ND & $\mathrm{ND} \sim 57$ & $\mathrm{ND} \sim 5$ & $\mathrm{ND} \sim 12$ & ND & $1.6 \sim 2.0$ & $0.5>$ & ND \\
\hline
\end{tabular}

These are 5 samples of each foodstuff except eggs ( 3 in No. 1 and 2 in No. 2). ${ }^{*}$ : Mean of two samples. No. 1 and No. 2 chicken feeds were produced in AMINOSHIRYO and CHIBA KUMIAISHIRYO Co., respectively. ** : Each sample of two chickens fed on feed No. 1 or No. 2 is MOMO, and the others are SASAMI. ND : not detected. 
高宮：残留性有機塩素化合物による人体及び食品の污染と ブリの污染指標としての役割

Table 5 OCI and lipid contents in young and mature yellowtails.

\begin{tabular}{|c|c|c|c|c|c|c|c|c|c|c|c|}
\hline Sample & & $\alpha-\mathrm{BHC}$ & $\beta$-BHC & $\gamma$-BHC & $\mathrm{pp}^{\prime} \cdot \mathrm{DDT}$ & $\mathrm{pp}^{\prime} \cdot \mathrm{DDE}$ & $o p^{\prime} \cdot \mathrm{DDT}$ & $\mathrm{pp} \cdot \mathrm{DDD}$ & $\Sigma D D T$ & Dieldrin & Lipid* $^{*}$ \\
\hline \multirow{2}{*}{ Young } & Range & $0.7 \sim 2.2$ & \multirow{2}{*}{ ND } & $0.5>$ & $1.8 \sim 8.0$ & $2.3 \sim 5.8$ & $\mathrm{ND} \sim 3.5$ & $\mathrm{ND} \sim 3.0$ & $2.3 \sim 19$ & \multirow[t]{2}{*}{-} & $2 \sim 3$ \\
\hline & $\mathrm{M} \pm \mathrm{SD}$ & $1.6 \pm 0.59$ & & $0.4 \pm 0.23$ & $6.2 \pm 2.5$ & $4.4 \pm 1.3$ & $2.1 \pm 1.3$ & $1.3 \pm 1.3$ & $14 \pm 6.6$ & & $2.4 \pm 0.54$ \\
\hline \multirow{2}{*}{ Mature } & Range & $2.0 \sim 3.6$ & \multirow{2}{*}{ ND } & \multirow{2}{*}{$\mathrm{ND} \sim 0.7$} & $11 \sim 39$ & $10 \sim 37$ & $4.0 \sim 14$ & $3.6 \sim 13$ & $29 \sim 103$ & $1.0 \sim 5.3$ & $3 \sim 12$ \\
\hline & $\mathrm{M} \pm \mathrm{SD}$ & $2.2 \pm 0.87$ & & & $22 \pm 13$ & $20 \pm 11$ & $7.8 \pm 3.9$ & $8.6 \pm 3.6$ & $58 \pm 29$ & $2.6 \pm 1.9$ & $7.8 \pm 3.8$ \\
\hline \multirow{2}{*}{ Young } & Range & $3.4 \sim 5.2$ & \multirow{2}{*}{ ND } & \multirow{2}{*}{$\mathrm{ND} \sim 0.8$} & $16 \sim 26$ & $8.4 \sim 11$ & $3.2 \sim 5.6$ & $5.6 \sim 11$ & $33 \sim 54$ & $3.0 \sim 4.8$ & $9 \sim 13$ \\
\hline & $\mathrm{M} \pm \mathrm{SD}$ & $4.4 \pm 0.65$ & & & $22.4 \pm 4.3$ & $9.7 \pm 0.97$ & $4.8 \pm 1.0$ & $9.0 \pm 2.1$ & $46 \pm 8.5$ & $4.1 \pm 0.68$ & $12 \pm 1.6$ \\
\hline Mature & Range & $8.3 \sim 15$ & \multirow{2}{*}{ ND } & $1.7 \sim 2.4$ & $14 \sim 53$ & $22 \sim 39$ & $\mathrm{ND} \sim 14$ & $23 \sim 35$ & $76 \sim 134$ & $5.8 \sim 19$ & $18 \sim 24$ \\
\hline Mature & $\mathrm{M} \pm \mathrm{SD}$ & $12 \pm 2.8$ & & $2.2 \pm 0.27$ & $33 \pm 17$ & $31 \pm 6.9$ & $4.6 \pm 4.9$ & $29 \pm 4.4$ & $99 \pm 26$ & $14 \pm 5.5$ & $22 \pm 2.3$ \\
\hline
\end{tabular}

¿DDT : $\mathrm{pp}^{\prime}-\mathrm{DDT}+\mathrm{pp}^{\prime} \cdot \mathrm{DDE}+\mathrm{op}^{\prime} \cdot \mathrm{DDT}+\mathrm{pp}^{\prime} \cdot \mathrm{DDD},{ }^{*}: \%(\mathrm{v} / \mathrm{w})$.

(ppb, whole basis)

認められた。魚の体内の DDT 関連化合物は,ブリではお およそ $\mathrm{pp}^{\prime}$-DDT $\fallingdotseq \mathrm{pp}^{\prime}$-DDE $>\mathrm{op}^{\prime}$-DDT $\fallingdotseq \mathrm{pp}^{\prime}$-DDD, アジ では $\mathrm{pp}^{\prime}$-DDT $>\mathrm{pp}^{\prime}$-DDE $\fallingdotseq \mathrm{op}^{\prime}$-DDT $\fallingdotseq \mathrm{pp}^{\prime}$-DDD の関係 が認められた。

dieldrin は，ブリの全検体に検出されたほかアジでは 2/5の検出率であり, マグロには検出されなかった。その 残留值は DDT の場合と同じく, ブリ>アジ>マグロて あった。

BHC は， $\alpha$ 異性体がブリとアジに $100 \%$ 検出されたも のの $\beta, \mathrm{r}$ 異性体は検出率が低く残留レベルも検出限界 であった。 $\alpha$-BHCの 3 種の魚への残留傾向は, DDT・ dieldrin と同椂であった。

\section{2 脂肪性食品の OCI 残留値}

$\mathrm{pp}^{\prime}$-DDT, $\mathrm{DDE}$ が豚脂の生と調理したもののいずれに も，ほほ同レベルで検出されたほか DDEがバターに 16〜20 ppb の範囲で100\%検出されたが，マーガリンに は全く検出されなかった。

BHCでは， $\alpha$ 異性体が豚脂とバ夕ーに検出されたが, バターのレベルが数倍高かった。

\section{3 鵴卵・鷄肉に残留する $\mathrm{OCI}$}

2 種類の飼料で飼育したそれぞれの養鵴の卵と肉につ いて, 分析結果を Table 4 にまとめた。

飼料No. 1 由来の養鷄では, 卵に比較的高い DDT の 蓄積が認められ, 飼料 No. 2 由来の卵と比較すると, 総 DDT で約 5 倍, pp'-DDT では10倍に達した。これに対し て, モモ肉には, No.1の場合総 DDT で卵の高々 $50 \%$ 濃 度であり，No.2のそれには全く検出されなかったほか， 市販のササミ肉にも DDT を始め他の OCI は, 検出され なかった。

3. ブリに残留する OCI の特徵と残留值の推移
Table 4 に要約した一次調查の結果から,検索した OCI が一様にブリに高值であったため, ブリに関して, 天然産と養殖産, 幼魚と成魚の比較, 体内分布及び DDT ・ dieldrin の推移を調查した。

\section{1. 天然産と養殖産の比較}

総 DDT・dieldrin 共に養殖産のレベルが高く, 成魚で の相対比では総 DDT で1.7倍, dieldrin では5.4倍であ った (Table 5)。

DDT 関連化合物の残留の特徵は, 天然産では, 幼魚, 成魚にかかわらず $\mathrm{pp}^{\prime}$-DDT と DDE が同レベル， $\mathrm{op}^{\prime}$ $\mathrm{DDT}$ と $\mathrm{pp}^{\prime}$-DDD が同レベルで, 前者のレベルが後者の 約 2 倍であった。養殖魚では, $\mathrm{pp}^{\prime}-\mathrm{DDT} \geqq \mathrm{pp}^{\prime}-\mathrm{DDE} \fallingdotseq \mathrm{pp}^{\prime}$ $\mathrm{DDD}>\mathrm{op}$-DDT の関係が認められた。

\section{2 幼魚・成魚の DDT, 脂質値と DDT の代謝}

Table 5 に示すように, 天然産と養殖産のいずれの場 合でも, 脂質と総 DDT 值共に成魚の方が高く, 幼魚と成 魚の間に扔抢よその平行関係が認められた。又, 総 DDT と脂質の含量は, 養殖の成魚が最も高く, 最低の天然産 の幼魚と比較すると, 総 DDT で7.1倍, 脂質では9.2倍に 達した。

天然産と養殖産について，DDT 関連化合物それぞれ の幼魚に対する成魚の增加率を比べると，いずれの場合 でも, 代謝物である $\mathrm{pp}^{\prime}-\mathrm{DDE}, \mathrm{pp}^{\prime}$-DDDの増加率が pp'-DDT，op'-DDT のそれよりも高い。

\subsection{OCI と脂質の体内分布}

天然ブリの各部位の脂質及び DDT・dieldrin の含有值 を Table 6 に示したが, 脂質とDDT, dieldrin の分布が 良く一致している。各部位の脂質レベルは, 腹部が最高 で30\%に達し，近頭部と背部がほほ同程度でこれに次ぎ， 尾部が最低で, 腹部は尾部の約15倍であった。 
Table 6 Distribution of DDT, dieldrin and lipid in a wild yellowtail.

\begin{tabular}{lccc}
\hline Portion & $\begin{array}{c}\Sigma \text { DDT } \\
\text { ppb(Ratio) }\end{array}$ & $\begin{array}{c}\text { Dieldrin } \\
\text { ppb(Ratio) }\end{array}$ & $\begin{array}{c}\text { Lipid } \\
\% \text { (Ratio) }\end{array}$ \\
\hline Near head & $103(3.3)$ & $3.8(3.4)$ & $8(4.0)$ \\
Rear & $84(2.7)$ & $2.9(2.6)$ & $6(3.0)$ \\
Abdomen & $408(13)$ & $14(13)$ & $30(15)$ \\
Near tail & $31(1.0)$ & $1.1(1.0)$ & $2(1.0)$ \\
\hline
\end{tabular}

Ratios of each portion vs "near tail" are given in parentheses. This yellowtail was obtained in Mar. 1979 , and its body weight was about $10 \mathrm{~kg}$.

\subsection{DDT 值の推移}

'79年から '83年に渡って, 隔年ごとに総 DDT 值(湿重 量当たり)の平均值と標準偏差を比較した（Fig. 1 (a))。'83年では, 天然産，養殖産のいずれの場合も, '81 年と比べて, 減少の傾向がみられた。

Fig. 1(b)に, pp'-DDT の総 DDT に占める割合を同様 に図示した。天然ブリでは, '81年には高い量的レベルに 付随して, その平均值が高く $50 \%$ ありり, 79 年と比べて 有意に高いほか, '83年には, '81年と比べて, いずれの場 合も量的減少傾向に伴い有意に低下した。

3.5 '81年天然ブリの残留 DDT について

天然ブリでは, '81年に総 DDT 值の顕著な増加がみら れたが，その場合の各試料について DDT の代謝・分解物 である $\mathrm{pp}^{\prime}$-DDE, $\mathrm{pp}^{\prime}$-DDD の総 DDT に占める割合, 脂 質値, 脂質当たりの総 DDT 值などの関連を一覧表にし た (Table 7)。

この中で, 長崎で水揚げされた試料では, 代謝・分解 物の割合が一様に30\%台で，他の 2 試料がほほ $50 \%$ であ (a)

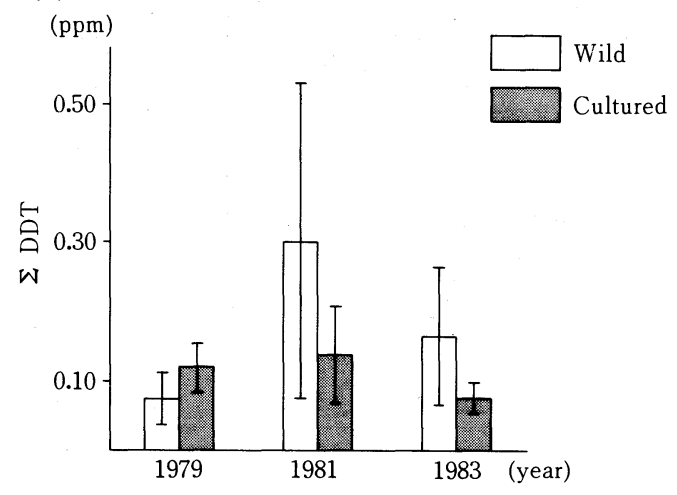

(b)

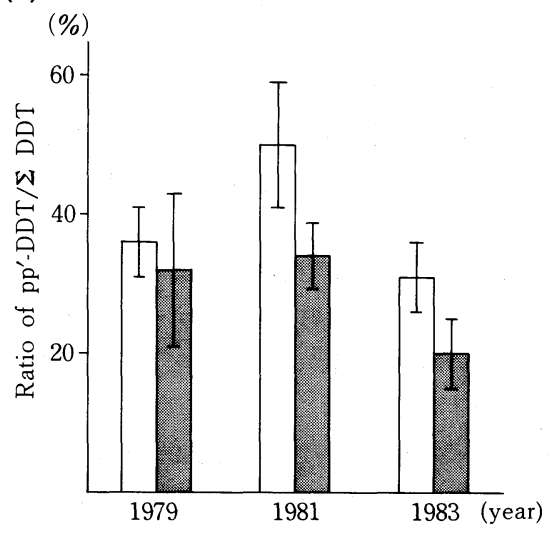

Fig. 1 Fluctuations of $\Sigma$ DDT contents and ratios of $\mathrm{pp}^{\prime}-\mathrm{DDT} / \Sigma \mathrm{DDT}$ in two kinds of yellowtails.

The ratio of $\mathrm{pp}^{\prime}$-DDT/ $\Sigma$ DDT of wild type in 1981 is significantly higher than two years before $(p<0.05)$. Similarly, levels of both types in 1983 are significantly lower than 1981 levels $(p<0.01)$.

Table 7 DDT content and its constituent in the yellowtail in 1981.

\begin{tabular}{|c|c|c|c|c|c|c|}
\hline \multirow{2}{*}{ Sample } & & \multicolumn{2}{|c|}{$\Sigma \mathrm{DDT}(\mathrm{ppm})$} & \multirow{2}{*}{$\begin{array}{l}\text { Lipid } \\
\text { (v/w\%) }\end{array}$} & \multirow{2}{*}{$\frac{\mathrm{DDE}+\mathrm{DDD}}{\Sigma \mathrm{DDT}}(\%)$} & \multirow{2}{*}{$\begin{array}{c}\text { Areas caught } \\
\text { or cultured }\end{array}$} \\
\hline & & whole basis & fat basis & & & \\
\hline \multirow{5}{*}{ Wild } & 1 & 0.42 & 8 & 5 & 37 & Nagasaki \\
\hline & 2 & 0.48 & 8 & 6 & 38 & Nagasaki \\
\hline & 3 & 0.80 & 10 & 8 & 35 & Nagasaki \\
\hline & 4 & 0.048 & 1 & 4 & 45 & Kagoshima \\
\hline & 5 & 0.18 & 2 & 7 & 53 & Unknown \\
\hline \multirow{5}{*}{ Cultured } & 1 & 0.13 & 0.59 & 22 & 56 & Uwajima \\
\hline & 2 & 0.15 & 0.68 & 22 & 58 & Uwajima \\
\hline & 3 & 0.075 & 0.44 & 17 & 53 & Kagoshima \\
\hline & 4 & 0.18 & 0.90 & 20 & 63 & Kagoshima \\
\hline & 5 & 0.32 & 1.2 & 26 & 48 & Kagoshima \\
\hline
\end{tabular}




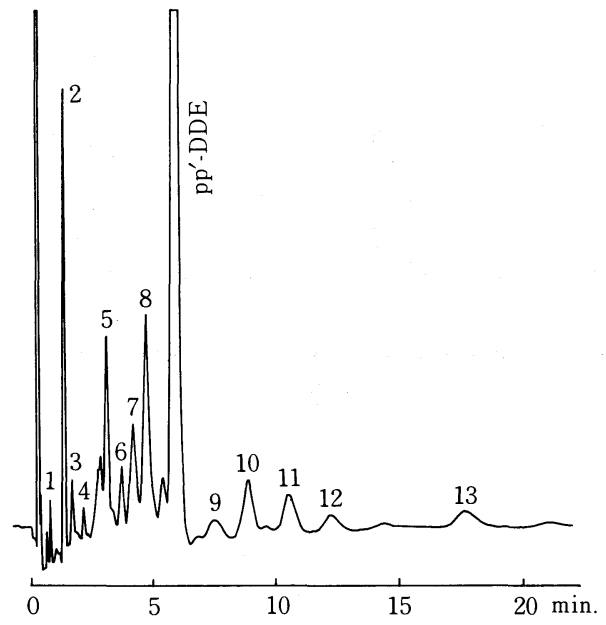

Fig. 2(a) Gaschromatographic patterns of PCB residues.

A $2 \mathrm{~m} \times 3 \mathrm{~mm}$ glass column packed with $2 \%$ OV -17 on Chromosorb W was used to perform GLC.

るのに比べて，かなり低い。又，養殖産では，48～63\% と概して高い。

次に, 脂質当りの総 DDT 值についてみると天然産で は, 長崎由来の試料が $8 \sim 10 \mathrm{ppm}$ と他の 2 試料に比べ

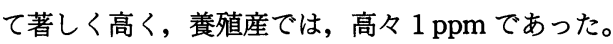

3.6 '81年天然ブリの $\mathrm{PCB}_{\mathrm{s}}$ ガスクロマトグラムパタ ーン

'81年試料の $\mathrm{PCB}_{\mathrm{s}}$ ガスクロマトグラムとそのパター ンを Fig. $2(\mathrm{a})$ (b)に掲げた。養殖産では, 各ピークを平均 値と標準偏差で示したが, ピーク No. 12 を除いて, いず れのピークの場合も変動係数が $30 \sim 40 \%$ とほほ一定の範 囲にあり, 試料による変動幅が小さく, 産地による相違 も明らかではない。

これに対して, 天然ブリでは水揚げ地域による相違が 顕著にみられ, 千葉県鴨川由来の試料の場合は, それぞ れのピークがすべて養殖産のピークの変動幅内にあり, 従ってそのパターンは養殖産のそれに一致している。次 に, 長崎由来の試料については, 各ピークを平均值で示 したが，基準ピークが最も高くその他のピークは，いず

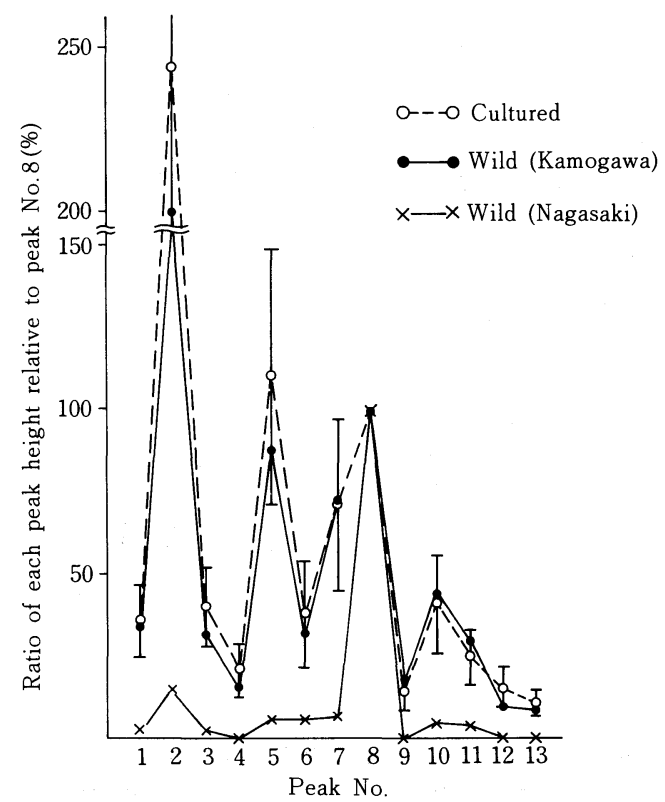

Fig. 2(b) PCBs gaschromatogram patterns of wild yellowtails and the areas where they were caught.

The peak height of each peak No. is showed as the value relative to peak No. 8. Mean and SD are given in the cultured type and mean in the wild type from Nagasaki area.

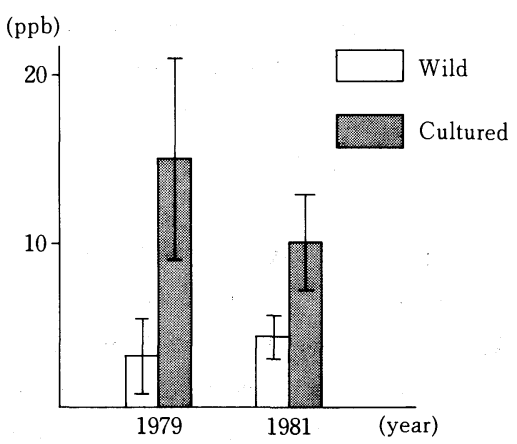

Fig. 3 Fluctuations of dieldrin content.

\section{れも極端に低い。}

\subsection{Dieldrin 值の推移}

DDT にならって, dieldrin の残留値の推移を Fig. 3 に 掲げた。'79年と'81年のいずれでも, 養殖魚のレベルが高 く, '81年ではやや低下したものの, 平均值レベルは, 天 然魚の約 2 倍であった。

4.ブリの PCB 污染について 


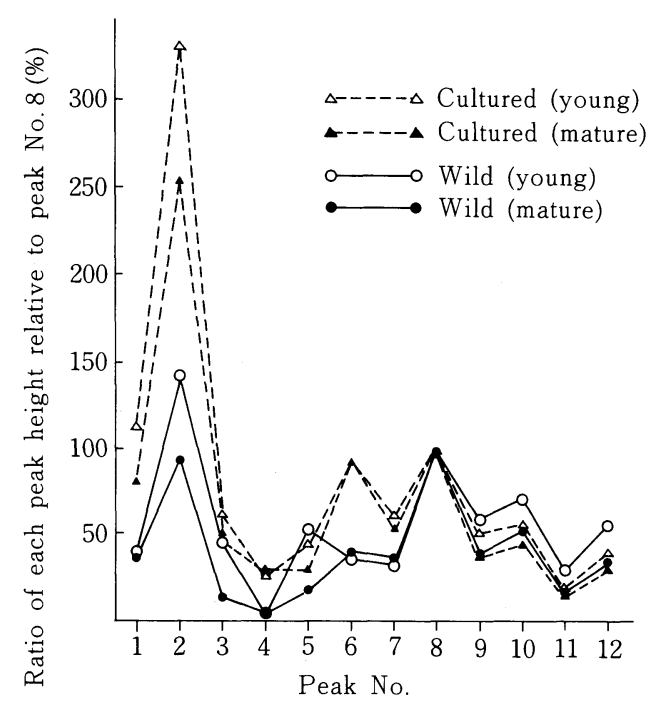

Fig. 4 PCBs gaschromatogram patterns of mature yellowtails as compared with young ones.

A $2 \mathrm{~m} \times 3 \mathrm{~mm}$ glass column packed with $2 \%$ OV -17 on Chromosorb W was used to perform GLC. These were 5 samples from each type and these yellowtails were obtained during the period from Dec. 1979 to Mar. '80. The mean body weights of mature fishes were about 8 times those of young ones for both types, i.e. those of young and mature fish are 1.1 and $8.6 \mathrm{~kg}$, respectively for wild types, and 0.57 and $4.6 \mathrm{~kg}$ for cultured fish.

\section{1 幼魚と成魚の $\mathrm{PCB}_{\mathrm{s}}$ ガスクロマトグラムパター ン}

Fig. 4 に示すように, 検索した12本のピークの中で, 天 然魚にはNo.4のピークが検出されなかった。

養殖魚では, 天然魚に比べて $\mathrm{pp}^{\prime} \cdot \mathrm{DDE}$ 以前に溶出され るピークが一般的に高い傾向を示した。幼魚と成魚を比 べると, 天然の成魚では, No. 3 のピークが危険率 $1 \%$ 以 下で有意に低下したほか, No. 2 と No. 9 の場合, 危険率 $5 \%$ 以下の有意な低下が認められた。又, 養殖の成魚で も, No. 2 のピークに, 危険率 $1 \%$ 以下の有意な低下がみ られたほか, No. 3 とNo.9にも，その傾向がみられた。

\section{$4.2 \mathrm{PCB}$ 含有值とその推移}

'80年，'82年及び '83年の試料について，残留 $\mathrm{PCB}_{\mathrm{s}}$ を 定量し, 平均値と標準偏差を Fig. 5 亿示した。天然産と 養殖産のレベルを比べると, '80年では平均值がほぼ等し く約 $0.1 \mathrm{ppm}$ であった。天然産では, その後変化なく養

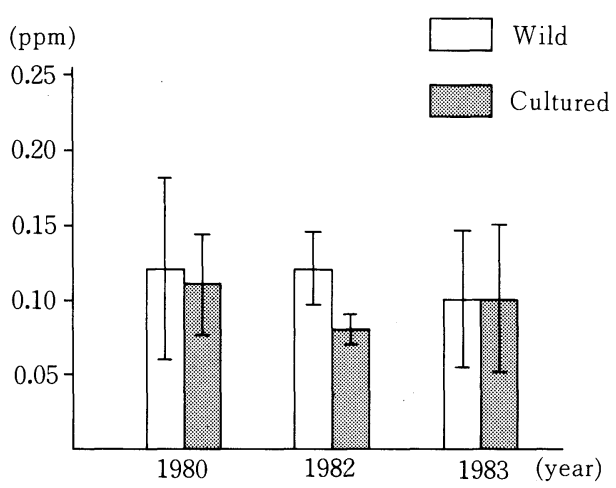

Fig. 5 Fluctuations of PCB contents in two kinás of yellowtails.

(a) patterns in 1980

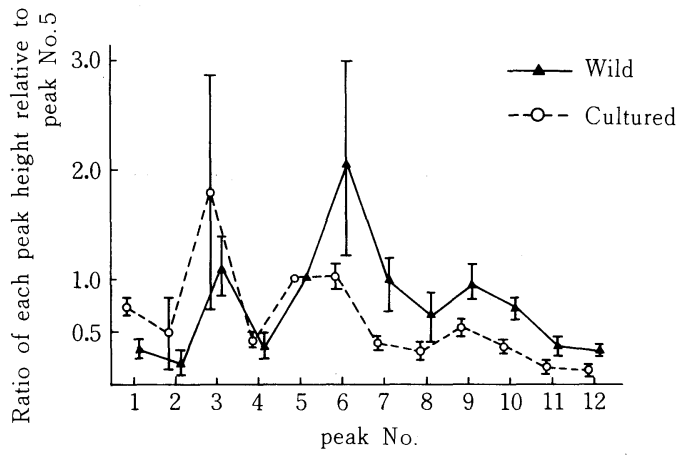

(b) patterns in 1982

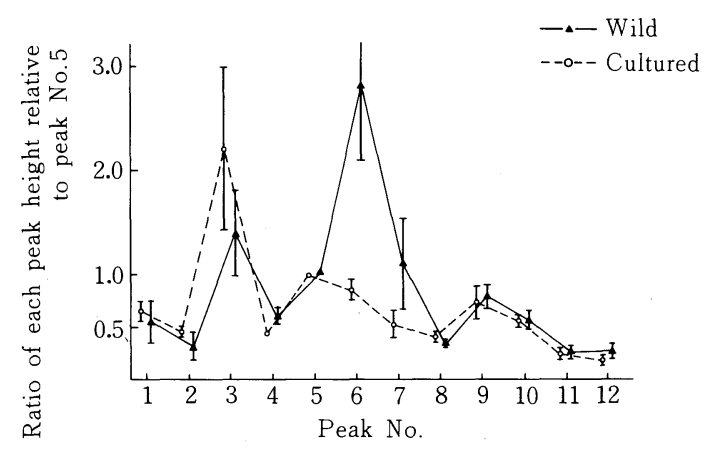

Fig. 6 PCBs gaschromatogram patterns in 1980 and 1982.

A $2 \mathrm{~m} \times 3 \mathrm{~mm}$ glass column packed with $2 \%$ OV -1 on Chromosorb $\mathrm{W}$ was used to perform GLC. The liquid phase of column packing and the peak No. as a basal peak are different from Fig. 4 in this case, therefore the shapes of GC gaschromatogram patterns are also different. 
殖産では, '82年のレベルがやや低いものの著しい変動は みられなかった。

\section{$4.3 \mathrm{PCB}_{\mathrm{s}}$ ガスクロマトグラムパターンの推移}

Fig. 6(a)に, '80年の天然産・㟍殖産それぞれのパター ンを示した。基準ピーク（No.5）を境にして相互に交差 しており,初期のピーク,殊にNo.1では明らかに養殖産 が高い。基準ピークょり後の No. 6〜12では,逆に天然産 の方が高い。従って, 質的には養殖産の方が低塩素化物 の比率が高く, 高塩素化物の比率は天然産が高いと言え る。

'82年では, Fig. 6(b)に示したが, 基準ピーク前後の No. 4, 6, 7 で天然産が高く, 殊にNo.6ではその差が顕 著であるが, その他のピークではほほ一致している。概 して, 2 年前と比べて相互の構成成分が近似してきたと 言える。

\section{考察}

人体に残留する OCI の特徴は, 脂肪組織への著しい親 和性と蓄積 ${ }^{25,26)}$ であり，人体に及ぼす有害影響という視 点からは, 神経毒 ${ }^{13)}$ であることと野鳥の生殖への影響 ${ }^{11)}$ から, 本調査で脊髄と種々の内分泌ホルモンの産生に関 与する副腎に, 比較的高いレベルの残留が認められた点 が注目される。又, $\beta$ - $\mathrm{BHC} \cdot \mathrm{pp}^{\prime}-\mathrm{DDE} \cdot$ dieldrin の人体 内分布 $($ Table 1$)$ から, 人体脂質への蓄積性は, $\beta$-BHC と $\mathrm{pp}^{\prime}$-DDE が同程度で dieldrinよりも高いものと推察 される。

$\beta$ - $\mathrm{BHC}$ と $\mathrm{pp}^{\prime}-\mathrm{DDE}$ の胎盤透過については, さい帯血

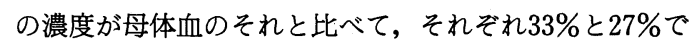

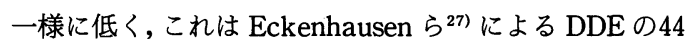
\%に比較的近似しているほか, PCBの Kodama ら ${ }^{28)}$ に よる21〜29\%, 同じく Akiyama ら ${ }^{29)}$ の約 $40 \%$ と同程度 であること, そのほか胎盤自身の脂質レベルが低く ${ }^{30)}$, $\beta-\mathrm{BHC} \cdot \mathrm{pp}^{\prime}-\mathrm{DDE}$ が胎盤には母体血とほほ同レベルでし か残留していないことから, 胎盤に, これらの透過を阻 止するなんらかの防禦機構の存在する可能性が考えられ る。

一般住民の OCI 污染源と推察される若干の食品を調 査したところ, 海洋性魚類の残留值が比較的高く, その 中でも大型魚で脂質に富むブリに高值であった。しかし， 魚の種類による差が顕著 ${ }^{31)}$ であり, ブリでは天然産・養 殖産にかかわらず，成魚では幼魚に比し DDT 值と脂質 含量がほほ平行して高值を示したこと, そのほかマグロ は大型魚であるにもかかわらず, 脂質值と OCI 值がいず れも低いことから, 魚種による OCI 残留の差の要因とし
て海流・緯度8) などのほかに堀ら ${ }^{31)}$ が指摘しているよう に, 脂質値が挙げられる。

ブリの養殖産と天然産を比較した成績（Table 5）で は, 幼魚・成魚のいずれでも養殖産の方が DDT 值・脂質 值共に高い。更に, 養殖産の天然産に対する比率は, DDT よりも脂質の方が幼魚・成魚のいずれでも高い。この点 について, 養殖魚では運動量が少ないための肥満32) が考 えられる。そのほか, 天然産と養殖産の DDT 関連化合物 の構成が異なるが, 餌の相違を反映しているほか養殖産 では, その保存過程での微生物による代謝 ${ }^{33)}$ が考えられ る。

各種食品の DDT 残留に関して, 豚脂・鶏卵・鶏肉に は, 魚肉と異なり $\mathrm{op}^{\prime}-\mathrm{DDT}$ と $\mathrm{pp}^{\prime}-\mathrm{DDD}$ が検出されなか ったことは，ほ乳類・鳥類の高い代謝機能を示すものと 理解される。ブリでは, 幼魚に対する成魚の蓄積の比率 に関して, 代謝物である $\mathrm{pp}^{\prime}-\mathrm{DDE}, \mathrm{pp}^{\prime}-\mathrm{DDD} の$ 方が $\mathrm{pp}^{\prime}-\mathrm{DDT}, \mathrm{op}^{\prime}-\mathrm{DDT}$ よりも高い傾向にあることから, $\mathrm{PCB}$ と同じく, 成長に伴いこれらの代謝活性が上昇する ものと理解される。そのほか, 鶏卵に蓄積する OCIにつ いては，飼料の違いによって，かなりの差がみられたが， これは飼料にイワシ, サバなどを原料とする魚粉が, 約 10\%の割合で添加されているためと考えられる。

OCI の食品を介した人体移行について, 生態系の視点 から DDTをとり上げると, その食物連鎖による濃縮に ついては, Woodwell ら ${ }^{34)} に よ り$ 報告されている。本調 查では, DDT の脂質当たりの濃度が, 我が国の近海に生 息する魚類の中で最高レベルにあると推察されるブリで,

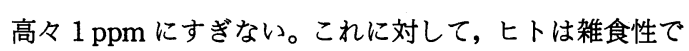
あるにもかかわらず, 菅谷ら゙によれば, 同時期に実施さ れた母乳と脂肪組織の平均值が, 脂質当たりでそれぞれ 約 $2.5 \mathrm{ppm}$ と約 $5 \mathrm{ppm}$ であることから, 食物連鎖による 濃縮が，脂質当たりでは成立していると考えられる。

天然の「ブリ」は, 日本列島の周辺に広く分布し, 回 遊する大型の遠洋魚であり, 冬期から翌春にかけて日本 近海で漁獲されることから, DDT 等の残留性有害化学 物質による海洋污染とそれに伴う魚介類及び一般住民の 污染を予測するうえで, 有力な指標と見なすことができ よう。

若干の調査ではあるが, DDT の場合, '81年の天然産で は, 試料の水揚げ地域によって顕著な差がみられ, その 中で DDT 值が最低の千葉県鴨川由来の試料では, その PCBs ガスクロマトグラムパターンが, 養殖産のそれに 類似していることから, その餌とされるイワシ・サバ類 を食して成長し, 比較的近海を生息水域としていたと推 
Table 8 DDT $\cdot$ dieldrin content of sardine (MAIWASHI).

\begin{tabular}{|c|c|c|c|c|c|c|c|}
\hline Sample* & $\mathrm{pp}^{\prime}-\mathrm{DDT}$ & $\mathrm{pp}^{\prime}-\mathrm{DDE}$ & $\mathrm{pp}^{\prime}-\mathrm{DDD}$ & $o p^{\prime}$-DDT & $\Sigma \mathrm{DDT}$ & Dieldrin & Lipid $^{* *}$ \\
\hline No. 1 & 5.4 & 10 & 3.6 & 2.7 & 22 & 2.0 & 12 \\
\hline No. 2 & 5.4 & 10 & 5.4 & 3.4 & 24 & 1.7 & 11 \\
\hline
\end{tabular}

${ }^{*}:$ These samples were obtained in Mar. 1983. ${ }^{* *}: \%(\mathrm{v} / \mathrm{w})$.

察される。これに対して, DDT 值が一様に高い長崎由来 の 3 尾では, PCBs のパターンが, 養殖産のそれと全く異 なることから，遠洋で成長したものと推察される。

ブリは, 春から夏にかけて黒潮に乗って, 本州沿岸を 北上し，秋から冬産卵のため南下するとされるが，その 途中漁獲される天然ブリは，俗に「寒ブリ」と言われる。 '81年の長崎のブリは, 入手時期が 3 月初旬で脂質含量が 低值であったことから，「寒ブリ」ではなく黒潮に乗って 北上していたものと推察される。そのほか, '81年の天然 産と養殖産の残留 DDT について, $\mathrm{pp}^{\prime}$-DDT・op'-DDT と $\mathrm{pp}^{\prime}$-DDT の代謝・分解物である $\mathrm{pp}^{\prime}-\mathrm{DDE}, \mathrm{DDD}$ の間 に, 次の量的関係が認められた。

天然産 $: \mathrm{pp}^{\prime}-\mathrm{DDT} \geqq \mathrm{pp}^{\prime}-\mathrm{DDE}>\mathrm{pp}^{\prime}-\mathrm{DDD} \fallingdotseq \mathrm{op}^{\prime}-\mathrm{DDT}$

養殖産： $\mathrm{pp}^{\prime}$-DDT $\fallingdotseq \mathrm{pp}^{\prime}$-DDE $>\mathrm{pp}^{\prime}$-DDD $>\mathrm{op}^{\prime}$-DDT 従って，天然産では総 DDT に占める原体成分の割合が 優位であり, 養殖産では逆に, 代謝・分解物のそれが僅 かながら優勢の傾向がみられた。更に, 天然産の中で, 長崎由来の 3 尾では原体成分の割合が最も高く, DDT 原体による污染が最も新しいものと理解される。

PCB の残留については, 天然産・養殖産のいずれも量 的にほほ同レべルで推移していることから，污染が長期 化するものと予測される。

養殖魚の場合, 餌を大量に与えるにもかかわらず, $\mathrm{DDT} \cdot \mathrm{PCB}$ それぞれの残留レベルが天然ブリのそれと 近似しているのは, 餌の相違と魚体の成長に伴う代謝機 能の変化によるものと考えられる。これに関連して, 養 殖魚の主要な餌であるイワシの残留值を Table 8 に示 したが，ほほ同時期の養殖魚と比べて，総 DDT 值では， その $1 / 3$ $/$ ベルであった。このように, 養殖産のブリと イワシの DDT 残留值に著しい差がみられない点につい

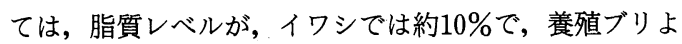
りも低值であることから，ブリの DDT 代謝機能がイワ シに比べて大きいためと推察される。

\section{要 約}

残留性の有機塩素系殺虫剤などによる人体と食品の污
染に関する若干の実態調查より，以下に記述する知見を えたほか，一般住民の污染予測にあたり，ブリを指標と する方法を考案した。

1) OCI の人体蓄積については, 脂肪組織への分布が 著明で，その蓄積性については， $\beta$-BHC と $\mathrm{pp}^{\prime}-\mathrm{DDE}$ が 同程度, dieldrin ではやや低い傾向がみられた。

2 ) 産婦の出産時さい帯血の $\beta-\mathrm{BHC}$ と $\mathrm{pp}^{\prime}-\mathrm{DDE}$ の 濃度は, いずれも一様に母体血の約 $30 \%$ でいずれの場合 も，さい帯血と母体血の濃度間に有意の相関性がみられ た。

3) 大型の回遊魚であるブリとマグロ及び近海魚のア ジにみられる DDT・dieldrin の残留傾向は同様で,ブ リ>アジ>マグロの順に蓄積性が認められ, 脂質含量が その主要な因子として挙げられる。

4 ）ブリの残留性有機塩素化合物は, 成長に伴い, 脂 質含量とほほ平行して増加すると推察されるほか, $\mathrm{DDT} \cdot \mathrm{PCB}$ の幼魚と成魚にみられる質的相違から, これ らの代謝機能の高まることが示唆された。

5 ）'81年の長崎で水揚げされた天然ブリの総 DDT 值が高かったのは, 質的にも原体成分の比率が高いほか PCBs ガスクロマトグラムパターンから, 黒潮の DDT 污染レベルが高かったためと推察された。

6 ) 生態系の視点から DDT 污染を考えると一般住民 と海洋性魚類の間に，食物連鎖による濃縮が，脂質当り では成立しているものと推察される。

7 ）ブリに残留する PCB の天然産と養殖産の質的相 違については, '80年ではピークパターンに明瞭な差異が みられたものの，その後漸次接近する傾向が観察された。 又, 量的には同レベルであり，おおむ横這いに推移し ていた。

8 ）ブリの DDT 残留の推移については, '83年に至つ て，質的量的に，減少の兆しが認められた。

謝辞

稿を終わるに臨み, 御指導と御助言をいただいた内田 昭夫教授, 又試料の供与に御理解と御協力をたまわりま 
した井出源四郎教授と第一病理学教室, 和康会産婦人科 医院岩瀬秀一博士に深謝致します。

\section{引用文 献}

1）菅谷 彪, 林 茂樹, 渡辺和広, 佐々木司郎: 人体 内における有機塩素系農薬及び PCB 残留量, 日農 誌, 30, 1- 5 (1981).

2）武田明治：農薬残留の動向, 公衆衛生, 45, 380384 (1981).

3）林 路彰：環境污染と母乳, 産婦人科の実際, 27 , 1075-1081 (1978).

4) Gupta, S.K., Parikh, J.R., Shah, M.P., Chatterjee, S.K. and Kashyap, S.K. : Changes in serum hexachlorocychlohexane residue in malaria spraymen after short-term occupational exposure, Arch. Environ. Health, 37, 41-44 (1982).

5) Goldberg, E.D. : Synthetic organohalides in the sea, Proc. R. Soc. Lond. B., 189, 277-289 (1975).

6）杉本良雄：昨年の国内・国外の消費事情, 農薬誌, 8, 257-259 (1983).

7) Da-Xiang Wang: The status of pesticides in china and their future, J. Pesticide Sci., 6, 397-399 (1981).

8) Tanabe, S. and Tatsukawa, R.: Chlorinated hydrocarbons in the north pacific and indian orceans, J. Oceanogr., 36, 217-226 (1980).

9) Meadows, D.H., Meadows, D.L., Randers, J. and Behrens III, W.W. 大来佐武郎監訳：成長の限界, p. 67, ダイヤモンド社, 東京 (1972).

10）レーチェル・カーソン著 青樹築一訳：生と死の妙 薬, 新潮社, 東京 (1964).

11) Peakall, D.B. : Physiological effect of Chlorinated hydrocarbons on avian species, Environmental Dynamics of Pesticides, p. 343-360, Plenum Press, New York and London (1975).

12）湯嶋 健, 金沢 純, 桐谷圭治: 生態系と農薬, p. 31, 岩波書店, 東京 (1973)。

13) Murphy, S.D.: TOXICOLOGY (Editor: J. Doull et al.), p. 379, Macmillan Publishing Co., New York (1980).

14) De Vlieger, M., Robinson, J., Baldwin, M.K., Crabtree, A.N. and Van Dijk, M.C. : The Organochlorine insecticide content of human tissues, Arch. Environ. Health, 17, 759-767 (1968).
15) Hayashi, Y.: Problems in the evaluation of carcinogenicity, Eisei Kagaku, 31, 15-18 (1985).

16) Wassermann, M., Tomatis, L., and Wassermann D. : Organochlorine compounds in the general population of the seventies and some of their biological effects (in man and animals), Pure and Applied Chemistry, 42, 189-208 (1975).

17) Oki, M., Maeda, K. and Takamatsu, M. : BHC, DDT and PCB levels in the plasma of farmers and others in asian countries, IAAMRH Journal, 7, 47-53 (1982).

18）堀 義宏, 新山和人：日常食による有機塩素化合物 の一日摂取量の推定について, 道衛研所報, 31，66 -69 (1981).

19）田辺弘也：残留農薬の分析, p. 74-76, 講談社, 東京 (1971).

20) Gaul, J.A., McMahon, B.M., and Corneliussen, $P$. E. : Pesticide Analytical Manual, 1, section 211. 13d, Rockville (1972).

21）脇本忠明, 立川 涼, 小川恒彦: PCB の残留分析 法, 公害と対策, 7, 43-48 (1972).

22）高松 誠，溝口敬子, 平山八郎, 井上純子：漁民油 症患者の血漿中 PCB 濃度とガスクロマトグラムパ ターンの特徵的所見, 福岡医誌, 70, 223-228 (1979).

23）能勢和夫, 秋好一夫 : 水, 土壤, 農作物に含まれる PCB の分析，農薬生産技術，30，29-36（1973）。

24) Takamiya, K. : Perchlorination reaction applied to the rapid determination of PCBs, Bull. Environ. Contam. Toxicol., 30, 600-605 (1983).

25) Robinson, J., Richardson, A., Hunter, C.G., Crabtree, A.N. and Rees, H.J.: Organochlorine insecticide content of human adipose tissue in south-eastern England, Brit. J. industr. Med., 22, 220-229 (1965).

26) Hunter, C.G. and Robinson, J.: Pharmacodynamics of dieldrin (HEOP). I. Ingestion by human subjects for 18 months, Arch. Environ. Health, 15, 614-626 (1967).

27) Eckenhausen, F.W., Bennett, D., Beynon, K.I. and Elgar, K.E. : Organochlorine pesticide concentration in perinatal samples from mothers and babies, Arch. Environ. Health, 36, 81-92 (1981).

28) Kodama, H. and Ota, H. : Transfer of polychlor- 
inated biphenyls to infants from their mothers, Arch. Environ. Health, 35, 95-100 (1980).

29) Akiyama, K., Ohi, G., Fujitani, K., Yagyu, H., Ogino, M., and Kawana, T.: Polychlorinated biphenyl residues in maternal and cord blood in tokyo metropolitan area, Bull. Environ. Contam. Toxicol., 14, 588-592 (1975).

30) Rappolt, R.T. and Hale, W.E. : pp'-DDE and $\mathrm{pp}^{\prime}$-DDT resides in human placentas, cords, and adipose tissue, Clin. Toxic, 1, 57-61 (1968).

31）堀 義宏, 丹川義彦, 山本勇夫, 設楽泰正, 佐藤芳 枝, 森 景夫, 故河井保人：農薬による食品の污染 について（第 7 報）1974年度北海道産乳肉食品, 魚
類中における農薬の残留状況, 道衛研所報, 25, 122 -125 (1975).

32）佐伯清子, 熊谷 洋: 天然および養殖八マチ肉にお ける部位別一般成分, 食衛誌, 20, 101-105 (1979).

33）山本出, 深見順一編, 鎯塚昭三：農薬, p. 546, ソフ トサイエンス社, 東京 (1979).

34) Woodwell, G.M., Wurster, C.F. and Isaacson, B. A.: DDT residues in an east coast estuary: a case of biological concentration of a persistent insecticide, Science, 156, 821-824 (1967).

（受付 1985年 6 月 7 日 受理 1985年11月 6 日） 